\title{
INSTITUTIONALIZATION AND EMOTIONAL LABOUR BEHAVIOUR: A RESEARCH IN HOSPITALITY ORGANIZATIONS
} Ali Şükrü ÇETINKAYA ${ }^{1}$

\author{
Emine Vasfiye KORKMAZ
}

\begin{abstract}
${ }^{3}$
Increase in competition and globalization makes it obligatory for businesses to lean towards differentiation in a competitive business environment. Businesses institutionalize and make efforts of differentiating their products and services toward their customers which enables them to proceed one step further than their competitors. The behavior of emotional labor is defined as the emotional expressions exhibited together with service by the employees. This empirical research investigated how institutionalization perception affected emotional labor behaviors. Survey technique was used as the data collecting instrument. Data, obtained from 393 employees working in tourism and hospitality businesses in Alanya, was analyzed through descriptive statistics, explanatory factor analysis and simple linear regression techniques. The result of the research revealed that the formalization dimension of institutionalization perception had significant positive effect on emotional labour behavior. That result implies that when an organization has written job descriptions and also written clear sets of rules that applicable for all, employees present more emotional labor.
\end{abstract}

Keywords: Institutionalization, Emotional labor, Tourism, Hospitality Organization, Service Industry

JEL Codes: M1, M12, Z32

\section{KURUMSALLAŞMA VE DUYGUSAL EMEK DAVRANIŞI: KONAKLAMA İ̧̧LETMELERİ ARAŞTIRMASI}

ÖZ

Artan rekabetçi iş ortamı ve küreselleşme işletmelerin farklılaşmaya yönelmesini zorunlu kılmaktadır. İşletmeler; kurumsallaşmaya çalışarak ve ürün ve hizmetlerini farklılaştırma gayreti göstererek rakiplerinden öne geçmeye çalışmaktadırlar. Duygusal emek davranışı, çalışanların hizmet verirken sergiledikleri duygusal ifadeler olarak tanımlanır. Bu ampirik araştırmada kurumsallaşma algısının duygusal emek davranışlarını nasıl etkilediği araştırılmıştır. Çalışmada veri toplama aracı olarak anket tekniği kullanılmıştır. Alanya'da turizm ve konaklama işletmelerinde çalışan 393 çalışandan elde edilen veriler, tanımlayıcı istatistikler, açıklayıcı faktör analizi ve basit doğrusal regresyon teknikleri kullanılarak analiz edilmiştir. Bulgular, kurumsallaşma algısının formalizasyon boyutunun, duygusal emek davranışı üzerinde anlamlı pozitif etkisinin olduğunu ortaya koymuştur. Araştırma sonucuna göre işletmelerde yazılı iş tanımları olduğunda ve herkes için geçerli olan anlaşılır yazılı kurallar olduğu zaman çalışanların daha fazla duygusal emek sergilemeye yatkın oldukları söylenebilir.

Anahtar Kelimeler: Kurumsallaşma, Duygusal Emek, Turizm, Konaklama İşletmeleri, Hizmet Sektörü

JEL Kodları: M1, M12, Z32

${ }^{1}$ Associate Professor (Doç. Dr), Selçuk Üniversitesi İktisadi ve İdari Bilimler Fakültesi, Turkey, alisukru@outlook.com

${ }^{2}$ Instructor (Ö̆gr. Gör.), Selçuk Üniversitesi Beyşehir Ali Akkanat Işsletme Fakültesi, Turkey, eminekorkmaz@selcuk.edu.tr

${ }^{3}$ Abstract of this research was presented at the 7th Advances in Hospitality and Tourism Marketing and Management (AHTMM) Conference in Famagusta, North Cyprus, July 10 - 15, 2017.

Makalenin Gönderim Tarihi: 12.08.2017; Makalenin Kabul Tarihi: 22.04.2018 


\section{INTRODUCTION}

An increase in competition and globalization has made it obligatory for businesses to have credible identities and be distinct in the business arena. A transfer of institutional identity to target segment can strengthen its institutional image by institutionalizing. Institutional identity is an attribute that distinguishes one business form another, and emphasizes on the businesses image (Bakan and Kefe, 2012: 29).

In a competitive environment where businesses institutionalize and make efforts to differentiate their products and services toward their customers, institutionalization gives them an upper hand compared to their competitors (Develioğlu, 2009: 9-10; Ebru Karpuzoğlu, 2001: 72). The way a businesses present their products and services in a different way in the business sector differentiating them from other businesses thus plays an important role especially for businesses in service sector where there is presence of intensive competitive.

Businesses in the service sector are obliged to have employees display emotions in the services they present. This introduces a different competitive understanding hence forth being preferred by their customers in that intensive competitive environment. This emotional expression, presented together with service, comes to our understanding as emotional labor in the literature (Delcourt, Gremler, De Zanet, and van Riel, 2017). The financial benefit of emotional labor is simply related to those who exhibiting positive attitudes toward customers, and more preferably compared to others, thus making more money. For waged employees, it can express the extra income they will acquire in the rate of high performance they exhibit (Oral and Köse, 2011: 473).

One important factor in employees' exhibiting emotional expression in meaning is also institutionalization perceptions of employees. It is said that institutionalization perception will cause employees to exhibit a more efficient and effective emotional labor behavior toward their customers.

\section{CONCEPTUAL FRAMEWORK}

\subsection{Institutionalization in Organizations}

Institutionalization is a process where a company has standards and procedures separately from people, it is where a business establishes systems that follow the changing environmental condition in accordance with developments hence forms its organizational structure. It turns methods of communication and task performance specific into a "culture" and disguise an identity that is different and distinctive from the other business (E. Karpuzoğlu, 2004: 45).

Institutionalization has an important role in the way a business operates. It makes businesses act in a more effective and efficient means through thoughts and applications such as environmental sensitivity, quality, customer satisfaction, and consistent business policies (Ulukan, 2005: 31). Institutionalization in businesses aims to maintain the interests of management, shareholders, and employees. It also increases the performance of managers, facilitates supervision, and encourages a 
company to use its own resources effectively. As a result of this, trust towards the company increases and capital cost of a company decreases (Kahraman, 2008: 23).

The main indicators of institutionalization of businesses are the development of organizational culture, professionalization of management, education - raising activities, viewpoint of institute to human, a systemic organizational structure, execution of activities in the light of certain plans and policies, standardization of work processes, and formation of internal audit system (Alkış and Temizkan, 2010: 74).

Institutionalization plays an important role in terms of how credible a business is toward its external periphery (Shabana, Buchholtz, and Carroll, 2017). Especially, in aligning positive judgments of employees to fore regarding the business they serve while having a positive course. In the developing and evolving modern age of businesses an increase in institutionalization perceptions enable employees to view themselves as an important part of the institute (Green, Li, and Nohria, 2009).

The fundamental component of institutional perception management is forming a perception that is possibly manageable. Institutional perception management is designed to influence the perceptions associated with the institution. The instruments presented here are image, credibility, and identity (Bakan and Kefe, 2012: 28). Image can also be defined as an impression a person, community or an organization has regarding itself. Image management of a business targeting the creation of effective image about its public relations (Çelik and Akgemci, 2010: 368).

Institutional image is defined by emotions as much as rational harmonization in an agency or group of people toward an institute (Peltekoğlu, 1997: 135). Institutional credibility expresses the net emotional reactions such as good, bad, weak or strong in the employees of business, its customers, investors, and all society regarding the name of the business (Bedük, 2011: 249).

Just as people have identities, institutes have also identities. This identity expresses the ethical values, aims, and their idiosyncratic state of institute that helps an organizations create differentiation in a competitive business environment (Bakan, 2011: 253).

Institutional image, institutional credibility, and institutional identity play a part in the thinking of both foreign customers and domestic customers and helps cause a positive or negative perception of the form. A businesses attaining institutionalization successfully with people who have positive institutional perceptions will increase the synergy and efficiency in the institute (Tefek, Çetinkaya, and Karayel, 2018).

Institutionalization deals with seven dimensions given by Apaydın (2008) which are simplicity, flexibility, autonomy, formalization, professionalism, transparency, and consistency. In that businesses make it more flexible, simple, transparent, and consistent with works in the organizational structures and the fact that they are in a structure sustaining their day to day activities along with professional managers and employees is important in term of institutionalization. 


\subsection{Emotional Labor}

While individuals defend their activities in business environments, which occur through their lives, it would not be wrong to say that they have many emotions and are intertwined with emotions. Especially in their work places where people stand out, communicate and interact usually, the significance and intensity of emotions begin to gain importance every day (Bağ $\mathrm{c}$ and Bursalı, 2015: $71)$.

Quality of service becomes possible with efforts and hastiness from employees, who are in communication with those receiving services. Emotions play an important role in the communication process and employees are asked to keep customer satisfaction a priority by using their emotions. In normal situations, emotion is intangible and has an idiosyncratic quality. Today it has become a tangible product and adds economic value (Basım and Beğenirbaş, 2012: 77). The increase of competition and globalization has made it obligatory for businesses to lean towards a differentiation path in their work presentations and services for their businesses to be able to survive. Especially, in the service sectors where humanistic approaches and communication are experienced more intensively, businesses advice their employees to assert their mental and physical strengths as well as emotional labor (Çetinkaya, Kaplan, and Ögüt, 2013).

Management of emotions is to adapt to job requirements, one should be able to form a clear facial and physical expression. Emotional labor is the effort, planning, and control to be shown as the desired emotion by the organization during visit relationships. Emotional labor is a concept which includes suppression, change, and imitation of emotions for shaping the emotional expression (Baş and K1lıç, 2014: 69). Jobs where emotional labor is exhibited have distinct features. Emotional labor is introduced where a job is in direct contact with the people hence employees need to use their emotions to create an emotional situation with the customers which enables them to control customers' emotions (Başbuğ, Ballı, and Oktuğ, 2010: 255).

Researchers targeted towards introduction of emotional labor and its sub dimensions, developed various approaches. In the framework of these approaches, the emotional behaviors of employees take place in two dimension: superficial role playing and in-depth role playing (Basım and Beğenirbaş, 2012: 79). Superficial role playing is when the employees behavior is compatible with institutional rules, which enables to them have different emotional expressions without showing the emotions really felt. In in-depth role playing, employee make empathy an internal emotion with an effort to understand people. For example, a cashier tries to seem to be interested in a customers' issues (Karim J and Weisz $\mathrm{R}, 2011)$. There can be certain behaviors employees display in this process which are natural emotional behaviors of employees and that can be considered as a third dimension. When employees display emotions they feel naturally they do not include responsibility, in the dimension of superficial and indepth role playing expresses how employees reflect their emotions impulsively (Basım and Beğenirbaş, 2012: 79). 
It is difficult to report emotional labor through a pattern, because emotional expressions affecting customer change according to each situation. While it is necessary for employees working for a holiday village to exhibit joyful and friendly behaviors, it is expected that those working in jobs such as funeral services to behave sadly while in a hospital employees are asked to exhibit joyful emotions for good results and joyless emotions for negative results (M. Çelik and Turunç, 2011: 228). The employees of a particular service sector are asked to have emotional labor behaviors exhibited in the forms and levels foreseen by the organization, in this kind of situation it bring togetherness of people working in jobs, it show features concerned intensively with make effort to exhibit emotional behaviors that are incompatible with their real feelings (Kaya and Özhan, 2012: 111).

\subsection{Institutionalization Perception and Emotional Labor}

For a good institutionalization perception, firstly an organization should form a good institutional image where it welcomes and salutes its customer in a smiling face; and addresses them by their names; talks to them in manner soft, convincing, and moderate voice tone; being careful about the words they say and style, emphasizes, and use of voice; speaking in clear and understandable way; facilitating and accelerating procedures; and carefully listening to one spoken agenda in achieving positive results on the name integrated to the public and in strengthening institutional image. These emotional labor behaviors increase institutionalization perception down to all employees - from security staff at the gate to general director (Gürbüz, 2004: 279).

Institutional credibility expresses value judgment forming in the minds of people in all business or some features it has. Institutional identity is a wide aspect which distinguishes a business from another. With institutional identity, the philosophy and strategy of a business is introduced (Bakan and Kefe, 2012).

Having good credibility effects on the talented staff members and encourages them to work in that institute. Hence the talented staff members work for the success of institute and in turn with the emotions they exhibit develops a strong customer relationship. On the other hand, a positive outcome reduces the staffs' expenditure, because the talented staff members want to work in the business where there's high credibility. Together with the recruitment of talented and educated staff numbers, education expenditures also decrease thus businesses having good credibility do not search for staff member. They spend less on labor and time for incorporating the qualified staff members (Ural, 2002: 89).

With institutional identity, businesses add value to their employees and are credible in the eyes of their employees and poses a competitive advantage. In an intensive competitive environment, keeping the performance of employees at a desired level creates institutionalization perception of employee and will cause them to belong to that business and view as their own job.

When businesses have a formal structure, formed with written rules; in this kind of structure the way to work are discussed in simple and are more flexible against the problems and developing conditions, they are consistent and have a transparent structure rather than a complex on; and extra 
information which supports the development of the employees and makes them more professional and are of important in steps necessary for institutionalization (Dağlar, 2015: 16). It is considered that these important steps taken under institutionalization will reflect the emotional expressions employees present to their customers.

As a result, emotional labor is a process where emotions are transferred by the employees of an organization together with the service they present to the customers. It is considered that institutionalization perception leads employees to exhibit more effective and efficient emotional labor behavior towards customer. This study has aimed to examine the effects of institutionalization perception of employees on their emotional labor behaviors. Employees working in the service sector, where they perform services in continuous communication with their customers, makes them in a state of continuous emotional labor expressions. The element of emotional labor can be possible viewed through the employees and their jobs which gives the best presentation of emotions and services, when employees take the institute like their own without harming its image and its credibility. Based on the literature review, the following hypothesis was proposed:

$\mathbf{H}_{1}=$ Institutionalization perception of employees positively affect their emotional labor behaviors.

\section{METHODOLOGY}

The aim of this quantitative research was to find out at what degree does institutionalization perceptions of employees affect their display of emotional labor while giving services to customers. A questionnaire with three parts was formed as the data collection instrument. The first part was about the demographic characteristics, the second part was the measure for the emotional labor behaviors, and the third part was the measure for the organizational performance.

The measure of the emotional labor was taken from the study developed by Diefendorff, Croyle and Grosserand and translated into Turkish by Basım and Beğenirbaş (2012). This 13-item measure had three dimensions, named as superficial role playing, in-depth role playing, and natural emotions. The items of this measure were formed in a 5-point Likert Scale in the form of " $1=$ never" and " $5=$ always". Cronbach's Alpha value for this measure was $\alpha=0.75$, which was considered good enough for internal consistency and reliability.

The measure for the institutionalization perception was developed by Apaydin (2008). This 40item measure had seven dimensions, named as simplicity, flexibility, autonomy, formalization, professionalism, transparency, and consistency. The items of this measure were formed in a 5-point Likert Scale in the form of " $1=$ Definitely disagree" and " $5=$ Definitely agree". Cronbach's Alpha value for this measure was $\alpha=0.99$, which was considered excellent for internal consistency and reliability.

The service sector is a place where employees usually make emotional expressions. Tourism and hospitality sector is among the areas in which emotional labor expression is used at most, and thus 
determined as the population of this research. The sample frame of the research was randomly selected employees working in tourism and hospitality firms in Alanya region. In this context, a sample size of 393 valid responses collected. This size is great enough to make generalization about the population when the population size is not known, confidence level is 0.95 , as suggested in the literature (Sait Gürbüz and Faruk Şahin, 2014). Before starting the main survey, a pilot study was conducted with 30 valid responses. Based on the results of pilot survey, and recommendations from four academics and three experts from the practice, the validity of the instrument maintained and the final version of the survey instrument determined.

\subsection{Demographics}

Table 1 depicts demographic characteristics of the sample. According to descriptive statistics, the individuals surveyed are dominantly male. Most of the respondents are married and at the age group of 25-49. Most of the respondents are at the high school and above education levels, and work in big sized organizations operating more than 10 years. Most of the respondents have above 4 years of work experience, working at the employee position at the housekeeping and food and beverage departments.

Table 1. Demographic Characteristics

\begin{tabular}{|c|c|c|c|c|c|c|c|}
\hline \multirow{5}{*}{ Gender } & & $f$ & $\%$ & & & $f$ & $\%$ \\
\hline & Male & 216 & 54,96 & \multirow{6}{*}{$\begin{array}{l}\text { Experience in } \\
\text { Current Job }\end{array}$} & Under 1 year & 21 & 5,34 \\
\hline & Female & 176 & 44,78 & & $1-3$ years & 113 & 28,75 \\
\hline & Missing & 1 & 25 & & 4-6 years & 172 & 43,77 \\
\hline & Total & 393 & 100,00 & & $7-9$ years & 57 & 14,50 \\
\hline \multirow{3}{*}{$\begin{array}{l}\text { Marital } \\
\text { Status }\end{array}$} & Married & 293 & 74,55 & & More than 10 years & 30 & 7,63 \\
\hline & Single & 100 & 25,45 & & Total & 393 & 100,00 \\
\hline & Total & 393 & 100,00 & \multirow{7}{*}{$\begin{array}{l}\text { Work } \\
\text { Experience in } \\
\text { Life }\end{array}$} & Under 1 year & 1 & 25 \\
\hline \multirow[t]{5}{*}{ Age } & $18-24$ & 108 & 27,48 & & $1-3$ years & 47 & 11,96 \\
\hline & $25-35$ & 153 & 38,93 & & 4-6 years & 123 & 31,30 \\
\hline & $36-49$ & 113 & 28,75 & & $7-9$ years & 103 & 26,21 \\
\hline & $50-65$ & 19 & 4,83 & & More than 10 years & 118 & 30,03 \\
\hline & Total & 393 & 100,00 & & Missing & 1 & 25 \\
\hline \multirow[t]{8}{*}{ Education } & Primary School & 32 & 8,14 & & Total & 393 & 100,00 \\
\hline & Junior Secondary School & 69 & 17,56 & \multirow[t]{6}{*}{ Status } & CEO/Asst. & 5 & 1,27 \\
\hline & Senior High School & 150 & 38,17 & & Supervisor/Foreman & 50 & 12,72 \\
\hline & Vocational high School & 57 & 14,50 & & $\begin{array}{l}\text { Section or Unit } \\
\text { Manager/Asst }\end{array}$ & 24 & 6,11 \\
\hline & Associate Degree & 55 & 13,99 & & Worker/Performer & 312 & 79,39 \\
\hline & Bachelor Degree & 29 & 7,38 & & Missing & 2 &, 51 \\
\hline & Master Degree & 1 & 25 & & Total & 393 & 100,00 \\
\hline & Total & 393 & 100,00 & \multirow{10}{*}{$\begin{array}{l}\text { Work } \\
\text { Department }\end{array}$} & Food and Beverage & 143 & 36,39 \\
\hline \multirow{5}{*}{$\begin{array}{l}\text { Years } \\
\text { Passed For } \\
\text { The Firm } \\
\text { Since its } \\
\text { Start-up }\end{array}$} & $1-3$ years & 20 & 5,09 & & Front Office & 24 & 6,11 \\
\hline & 4-6 years & 36 & 9,16 & & Housekeeping & 104 & 26,46 \\
\hline & $7-9$ years & 77 & 19,59 & & Management & 48 & 12,21 \\
\hline & More than 10 years & 260 & 66,16 & & Maintenance & 52 & 13,23 \\
\hline & Total & 393 & 100,00 & & Animation & 22 & 5,60 \\
\hline \multirow{4}{*}{$\begin{array}{l}\text { Total } \\
\text { Number of } \\
\text { Employee }\end{array}$} & $50-99$ & 66 & 16,79 & & \multirow[t]{4}{*}{ Total } & 393 & 100,00 \\
\hline & $100-249$ & 47 & 11,96 & & & & \\
\hline & $250-499$ & 280 & 71,25 & & & & \\
\hline & Total & 393 & 100,00 & & & & \\
\hline
\end{tabular}




\subsection{Explanatory Factor Analysis for The Measure of Emotional Labor}

Exploratory Factor Analysis (EFA) enables to decrease measurable and observable variables to fewer latent variables that have a common variance (Bartholomew, Knott and Moustaki, 2011). In order to perform a factor analysis, a univariate and multivariate normality must be present in the data and the determining factor will be based on the assumption that co-relations have a linear relationship between factors and variables (Yong and Pearce, 2013: 67).

The factor structure and assessment of scale validity determined by applying the principal component analysis using Oblimin method along with Kaiser Normalization. The correlation coefficient was all significant and higher than 0.38 . No item was dropped out because of multi-collinearity problem within the items. The Kaiser-Meyer-Olkin (KMO) and Bartlett tests $\left(\chi^{2}\right)$ were all significant, indicating that the correlation matrix is non-singular, data are normally distributed and consistent for principal component analysis. EFA brought out two dimensions for the measure emotional labor: natural emotions and surficial emotions. Table 2 summarizes the deriving key indicators.

Table 2. Explanatory Factor Analysis for The Measure of Emotional Labor

\begin{tabular}{|c|c|c|}
\hline \multicolumn{3}{|c|}{$\begin{aligned} \text { Kaiser-Meyer-Olkin Measure of Sampling Adequacy }= & 0,921 \\
\text { (Bartlett's Test of Sphericity)Approx. Chi-Square }(\chi 2) & =10.379 \\
\text { df (Degree of freedom }) & =78 \\
\text { Sig. }= & 0,000\end{aligned}$} \\
\hline \multirow[b]{2}{*}{ Pattern Matrix } & \multicolumn{2}{|c|}{ Components } \\
\hline & $\begin{array}{c}\text { natural } \\
\text { emotions }\end{array}$ & $\begin{array}{l}\text { artificial } \\
\text { emotions }\end{array}$ \\
\hline $\begin{array}{l}\text { S10 I make intensive effort so that I can feel the emotions I have to exhibit while } \\
\text { serving guests in myself }\end{array}$ & 0,931 & \\
\hline S11 The emotions I exhibit while serving guests are friendly. & 0,928 & \\
\hline $\begin{array}{l}\text { S8 In order to really feel tte.amiflgj.I have to show for customer satisfaction } \\
\text { white serving guests I make effort }\end{array}$ & 0,926 & \\
\hline $\begin{array}{l}\text { S9 In order to he afcle to feel the emotions I have to show for customer } \\
\text { satisfaction white serving guests. I do my best }\end{array}$ & 0,923 & \\
\hline S12 The show while serving guests appear spontaneously & 0,890 & \\
\hline $\begin{array}{l}\text { S13 The emotions I show while serving guests are the same as the ones I feel at } \\
\text { that moment. }\end{array}$ & 0,881 & \\
\hline S7. I try to really experience the emotions I have to show to the guests & 0,830 & \\
\hline S4 The emotions I do not feel while serving guest. I pretend feeling & & 0,965 \\
\hline S3 While serving guests. I exhibit extra performance as if I make show & & 0,958 \\
\hline S6 Toward guests, I exhibit the different emotions from the emotions I really feel & & 0,957 \\
\hline S2 While serving guests, I pretend feeling well for customer satisfaction & & 0,954 \\
\hline $\begin{array}{l}\text { S5 For being able to its able to exhibit the emotions my profession requires. I } \\
\text { pretend wearing a mask }\end{array}$ & & 0,944 \\
\hline S1 While serving guests, I play rob for customer satisfaction. & & 0,937 \\
\hline \multicolumn{3}{|c|}{$\begin{array}{l}\text { Extraction Method: Principal Component Analysis. Rotation Method: Oblimin with Kaiser Normalization. a. } \\
\text { Rotation converged in } 7 \text { iterations. } \\
\text { Natural emotions: Eigen value }=8.409 ; \text { Explained variance } \%=64.68 ; \alpha=0.96 \\
\text { Artificial emotions: Eigen value }=3.335 \text {; Explained variance } \%=26.66 ; \alpha=0.97 \\
\text { Total variance explained }=90.34 \%\end{array}$} \\
\hline
\end{tabular}




\subsection{Simple Linear Regression Analysis}

The measure for the perceived institutionalization was also tested by the explanatory factor analysis to ensure that data satisfied the dimensions as suggested by the literature. All dimensions rotated in one component separately. After ensuring the unidimensionality of the dimensions, a compound variable generated for each dimension. The reliability of the all dimensions were over $60 \%$ : simplicity: $\alpha=0.97$ (4 items); flexibility: $\alpha=0.97$ (4 items); autonomy: $\alpha=0.75$ (5 items); formalization: $\alpha=0.97$ (4 items); professionalism: $\alpha=0.97$ (9 items); transparency: $\alpha=0.97$ (6 items); and consistency: $\alpha=$ 0.99 (8 items).

Following factor analysis, in order to test the hypothesis and reveal the relationships between dimensions of emotional labor measure and dimensions of institutionalization measure, a regression analysis was conducted. Table 3 depicts the regression analysis results.

Table 3. Regression Analysis Results

\begin{tabular}{|c|c|c|c|c|c|c|c|c|}
\hline $\begin{array}{c}\text { Independent } \\
\text { Variables } \\
\end{array}$ & $\mathbf{R}^{2}$ & $\mathbf{R}^{2}$ Adjusted & $\begin{array}{c}\text { Dependent } \\
\text { Variable }\end{array}$ & $\begin{array}{l}\text { Std. } \\
\text { Error }\end{array}$ & $\mathbf{F}$ & B & $\mathbf{t}$ & $\mathbf{p}$ \\
\hline \multicolumn{9}{|l|}{ Model 1} \\
\hline Simplicity & \multirow{7}{*}{0,27} & \multirow{7}{*}{0,07} & \multirow{7}{*}{$\begin{array}{l}\text { Natural } \\
\text { Emotions }\end{array}$} & \multirow{7}{*}{0,958} & \multirow{7}{*}{$\begin{array}{c}4,342 \\
\mathrm{df}=7,385 \\
\mathrm{p}=0,000\end{array}$} & 0,045 & 0,469 & 0,640 \\
\hline Flexibility & & & & & & 0,049 & 0,468 & 0,640 \\
\hline Autonomy & & & & & & $-0,008$ & $-0,137$ & 0,891 \\
\hline Formalization & & & & & & 0,190 & 2,078 & 0,038 \\
\hline Professionalism & & & & & & $-0,033$ & $-0,287$ & 0,774 \\
\hline Transparency & & & & & & $-0,008$ & $-0,059$ & 0,953 \\
\hline Consistency & & & & & & 0,053 & 0,414 & 0,679 \\
\hline \multicolumn{9}{|l|}{ Model 2} \\
\hline Simplicity & \multirow{7}{*}{0,12} & \multirow{7}{*}{0,01} & \multirow{7}{*}{$\begin{array}{l}\text { Artificial } \\
\text { Emotions }\end{array}$} & \multirow{7}{*}{1,339} & \multirow{7}{*}{$\begin{array}{c}0,795 \\
d f=7,385 \\
p=0,000\end{array}$} & $-0,079$ & $-0,808$ & 0,420 \\
\hline Flexibility & & & & & & 0,147 & 1,372 & 0,171 \\
\hline Autonomy & & & & & & 0,019 & 0,335 & 0,738 \\
\hline Formalization & & & & & & 0,112 & 1,187 & 0,236 \\
\hline Professionalism & & & & & & $-0,026$ & $-0,218$ & 0,828 \\
\hline Transparency & & & & & & $-0,024$ & $-0,170$ & 0,865 \\
\hline Consistency & & & & & & $-0,158$ & $-1,186$ & 0,236 \\
\hline
\end{tabular}

Based on the results of the regression analysis, the proposed hypothesis of the research $\left(\mathrm{H}_{1}\right)$ was supported for the formalization dimension, but rejected for the rest of the institutionalization dimensions.

\section{CONCLUSION}

This research was carried out to examine the effect of institutionalization perception of employees on their emotional labor behaviors. Results of the simple linear regression analysis revealed that the dimensions of institutionalization perception (simplicity, flexibility, autonomy, formalization, and consistency) and had an effect on the natural emotional behavior. The relationship between formalization and natural emotional labour was positive and significant.

This finding implies that organizations should set up a formalized work place. Formalization has an important place in the institutionalization of enterprises and the removal of management from 
individuality and attaching it to certain rules and standards. It is necessary to create written job descriptions by defining the duties, authorities and responsibilities of all the employees within an enterprise. Formalization facilitates control of employees' actions and reduces conflicts.

Formalization can be ensured by having written job descriptions, written procedures and rules that are applicable to all. Once this satisfied, it is obvious that employees at the tourism and hospitality industry are willing to present more natural emotional labour.

This research had some limitation. Firstly, this research was restricted with Alanya region. Research can be conducted in the other parts of the country to make generalized comparisons. Secondly, this study was only focused on service sector. Future research can be extended on the other sectors. 


\section{REFERENCES}

Alkış, H., and Temizkan, V. (2010). İşletmelerin Kurumsallaşma Düzeylerinin Belirlenmesi: (Haddehaneler) Karabük Demir-Çelik Sektörü Örneği. Ekonomik Yaklaşım, 21(76), 73-92.

Bağcı, Z., and Bursalı, Y. M. (2015). Duygusal Emeğin İş Performansı Üzerindeki Etkisi: Denizli İlinde Hizmet Sektöründe Görgül Bir Araştırma. [The Impact Of Emotıonal Labor On Work Performance:An Ampırıcal Research In Servıce Sector In Denizli]. Kafkas Üniversitesi İktisadi İdari Bilimler Fakültesi Dergisi, 6(10). doi:10.18025/kauiibf.6.10.2015.16265

Bakan, İ. (Ed.) (2011). Yönetimde Çağdaş ve Güncel Yaklaşımlar. Ankara: Gazi Kitabevi.

Bakan, İ., and Kefe, i. (2012). Kurumsal Açıdan Alg1 Yönetimi. Kahramanmaraş Sütçü İmam Üniversitesi İktisadi İdari Bilimler Fakültesi Dergisi, 2(1), 19-34.

Basım, N. H., and Beğenirbaş, M. (2012). Çalışma Yaşamında Duygusal Emek: Bir Ölçek Uyarlama Çalışması. Yönetim ve Ekonomi, 19(1), 77-90.

Baş, M., and Kılıç, B. (2014). Duygusal Emek Boyutları, Süreci ve Sonuçlarının Engelli Turizm Pazarında Değerlendirilmesi. [The Evaluation of Aspects, Process and Results of Emotional Labour Within the Disabled Tourism Market]. Gazi Üniversitesi Turizm Fakültesi Dergisi, 2, 67-83.

Başbuğ, G., Ballı, E., and Oktuğ, Z. (2010). Duygusal Emeğin İş Memnuniyetine Etkisi: Çağrı Merkezi Çalışanlarına Yönelik Bir Çalışma. Sosyal Siyaset Konferansları Dergisi,, 58, 253-274.

Bedük, A. (2011). Örgüt Psikolojisi (A. Bedük Ed.). Konya: Atlas Akademi.

Çelik, A., and Akgemci, T. (2010). Girişimcilik Kültürü ve Kobiler. Ankara: Seçkin Kitabevi.

Çelik, M., and Turunç, Ö. (2011). Duygusal emek ve psikolojik sıkıntı: iş-aile çatışmasının aracilık etkisi. [Emotional labor and psychological distress: the mediating effect of work family conflict]. İstanbul Üniversitesi İşletme Fakültesi Dergisi, 40(2), 226-250.

Çetinkaya, A. Ş., Kaplan, M., and Öğüt, A. (2013, 30 Mayıs - 01 Haziran 2013). Duygusal Emek ile Tükenmişlik Arasındaki İlişkide Psikolojik Sermayenin Rolü. Paper presented at the 21. Yönetim ve Organizasyon Kongresi, Dumlupınar Üniversitesi, Kütahya.

Dağlar, H. (2015). Türkiye'de Organize Sanayi Bölgelerinin Kurumsallaşması ve Karşılaştıkları Sorunlara Çözüm Önerileri. Çankırı Karatekin Üniversitesi İktisadi ve İdari Bilimler Fakültesi Dergisi, $5(2), 615-638$.

Delcourt, C., Gremler, D. D., De Zanet, F., and van Riel, A. C. (2017). An analysis of the interaction effect between employee technical and emotional competencies in emotionally charged service encounters. Journal of Service Management, 28(1), 85-106.

Develioğlu, M. (2009). İşletmelerde Kurumsallaşma ve Kurumsal İletişimin Önemi İstanbul: İstanbul Ticaret Odas1.

Green, S. E., Li, Y., and Nohria, N. (2009). Suspended in Self-Spun Webs of Significance: A Rhetorical Model of Institutionalization and Institutionally Embedded Agency. The Academy of Management Journal, 52(1), 11-36. 
Gürbüz, D. (2004). Halkla İlişkiler ve Tanıtım Faaliyetlerinin Etkinliğinde İzlenim (İmaj) Yönetimi (Kurum İmajından Kişisel İmaja). Paper presented at the 2nd International Symposium Communication in the Millennium: A Dialogue Between Turkish and American Scholars, 17-19 March 2004, Istanbul University, Social Club of Istanbul University at Baltalimanı Baltalimanı, Emirgan, Istanbul, Turkey.

Kahraman, C. (2008). Kurumsal Yönetim Anlayışının Özel Sermayeli Bankaların Yapısı Ve İşleyişi Üzerine Etkileri. (Doktora Doktora), İstanbul Üniversitesi, İstanbul.

Karim J, and Weisz R. (2011). Emotions At Work: The Role Of Emotional Intelligence And Emotional Labor In Predictıng Work-Famıly Conflict, Psychological Distress, And Life Satısfaction. International Journal of Arts and Sciences, 4(3), 29-44.

Karpuzoğlu, E. (2001). Büyüyen ve Gelişen Aile Şirketlerinde Kurumsallaşma (1 ed.). İstanbul: Hayat Yayınevi.

Karpuzoğlu, E. (2004). Aile Şirketlerinin Sürekliliğinde Kurumsallaşma. Paper presented at the T.C. İstanbul Kültür Üniversitesi 1. Aile İşletmeleri Kongresi, İstanbul.

Oral, L., and Köse, S. (2011). Hekimlerin Duygusal Emek Kullanımı İle İş Doyumu Ve Tükenmişlik Düzeyleri Arasındaki İlişkiler Üzerine Bir Araştırma. [A Research On Phsıcıans' Use Of Emotıonal Labor And The Relatıonshıp Between Theır Job Satısfactıon And Burnout Levels]. Süleyman Demirel Üniversitesi İktisadi ve İdari Bilimler Fakültesi Dergisi, 16(2), 463-492.

Peltekoğlu, F. B. (1997). Kurumsal İletişim Sürecinde İmajın Yeri. Istanbul Üniversitesi Iletisim Fakültesi Dergisi, 125-146.

Sait Gürbüz, and Faruk Şahin. (2014). Sosyal Bilimlerde Araştırma Yöntemleri Felsefe Yönetim - Analiz. Ankara: Seçkin Yayıncılık.

Shabana, K. M., Buchholtz, A. K., and Carroll, A. B. (2017). The institutionalization of corporate social responsibility reporting. Business and Society, 56(8), 1107-1135.

Tefek, A., Çetinkaya, A. S., and Karayel, S. (2018). Institutionalization in SMEs. Paper presented at the 11th International Conference on New Challenges in Management and Business Hilton Istanbul Kozyatagi, Istanbul, Turkey.

Ulukan, C. (2005). Girisimcilerin ve Profesyonel Yöneticilerin Kurumsallasma Perspektifi. [Perspectives of Institutionalization of Entrepreneurs and Professional Managers]. Anadolu Üniversitesi Sosyal Bilimler Dergisi, 5(2), 29-42.

Ural, E. G. (2002). İtibar Yönetimi Değer Yaratan Bir Halkla İlişkiler Çalışması Olarak İtibar Yönetimi. İstanbul Ticaret Üniversitesi Dergisi, 1(2), 83-93.

Yong, A. G., and Pearce, S. (2013). A Beginner's Guide to Factor Analysis: Focusing on Exploratory Factor Analysis. Tutorials in Quantitative Methods for Psychology, 9(2), 79-94.Alkış, H., and Temizkan, V. (2010). İşletmelerin Kurumsallaşma Düzeylerinin Belirlenmesi: (Haddehaneler) Karabük Demir-Çelik Sektörü Örneği. Ekonomik Yaklaşım, 21(76), 73-92. 
Bağcı, Z., and Bursalı, Y. M. (2015). Duygusal Emeğin İş Performansı Üzerindeki Etkisi: Denizli İlinde Hizmet Sektöründe Görgül Bir Araştırma. [The Impact Of Emotıonal Labor On Work Performance:An Ampırıcal Research In Servıce Sector In Denizli]. Kafkas Üniversitesi Ikktisadi İdari Bilimler Fakültesi Dergisi, 6(10). doi:10.18025/kauiibf.6.10.2015.16265

Bakan, İ. (Ed.) (2011). Yönetimde Çă̆daş ve Güncel Yaklaşımlar. Ankara: Gazi Kitabevi.

Bakan, İ., and Kefe, i. (2012). Kurumsal Açıdan Alg1 Yönetimi. Kahramanmaraş Sütçü İmam Üniversitesi İktisadi İdari Bilimler Fakültesi Dergisi, 2(1), 19-34.

Basım, N. H., and Beğenirbaş, M. (2012). Çalışma Yaşamında Duygusal Emek: Bir Ölçek Uyarlama Çalışması. Yönetim ve Ekonomi, 19(1), 77-90.

Baş, M., and Kılıç, B. (2014). Duygusal Emek Boyutları, Süreci ve Sonuçlarının Engelli Turizm Pazarında Değerlendirilmesi. [The Evaluation of Aspects, Process and Results of Emotional Labour Within the Disabled Tourism Market]. Gazi Üniversitesi Turizm Fakültesi Dergisi, 2, 67-83.

Başbuğ, G., Ballı, E., and Oktuğ, Z. (2010). Duygusal Emeğin İş Memnuniyetine Etkisi: Çağrı Merkezi Çalışanlarına Yönelik Bir Çalışma. Sosyal Siyaset Konferansları Dergisi,, 58, 253-274.

Bedük, A. (2011). Örgüt Psikolojisi (A. Bedük Ed.). Konya: Atlas Akademi.

Çelik, A., and Akgemci, T. (2010). Girişimcilik Kültürü ve Kobiler. Ankara: Seçkin Kitabevi.

Çelik, M., and Turunç, Ö. (2011). Duygusal emek ve psikolojik sıkıntı: iş-aile çatışmasının aracıllk etkisi. [Emotional labor and psychological distress: the mediating effect of work family conflict]. İstanbul Üniversitesi Işsletme Fakültesi Dergisi, 40(2), 226-250.

Çetinkaya, A. Ş., Kaplan, M., and Ögüt, A. (2013, 30 Mayıs - 01 Haziran 2013). Duygusal Emek ile Tükenmişlik Arasındaki İlişkide Psikolojik Sermayenin Rolü. Paper presented at the 21. Yönetim ve Organizasyon Kongresi, Dumlupınar Üniversitesi, Kütahya.

Dağlar, H. (2015). Türkiye'de Organize Sanayi Bölgelerinin Kurumsallaşması ve Karşılaştıkları Sorunlara Çözüm Önerileri. Çankırı Karatekin Üniversitesi İktisadi ve İdari Bilimler Fakültesi Dergisi, $5(2), 615-638$.

Delcourt, C., Gremler, D. D., De Zanet, F., and van Riel, A. C. (2017). An analysis of the interaction effect between employee technical and emotional competencies in emotionally charged service encounters. Journal of Service Management, 28(1), 85-106.

Develioğlu, M. (2009). İşletmelerde Kurumsallaşma ve Kurumsal İletişimin Önemi İstanbul: İstanbul Ticaret Odası.

Green, S. E., Li, Y., and Nohria, N. (2009). Suspended in Self-Spun Webs of Significance: A Rhetorical Model of Institutionalization and Institutionally Embedded Agency. The Academy of Management Journal, 52(1), 11-36.

Gürbüz, D. (2004). Halkla Illişkiler ve Tanıtım Faaliyetlerinin Etkinliğinde İzlenim (İmaj) Yönetimi (Kurum Imajindan Kişisel Imaja). Paper presented at the 2nd International Symposium Communication in the Millennium: A Dialogue Between Turkish and American Scholars, 17-19 March 
2004, Istanbul University, Social Club of Istanbul University at Baltalimanı Baltaliman1, Emirgan, Istanbul, Turkey.

Kahraman, C. (2008). Kurumsal Yönetim Anlayışının Özel Sermayeli Bankaların Yapısı Ve İşleyişi Üzerine Etkileri. (Doktora Doktora), İstanbul Üniversitesi, İstanbul.

Karim J, and Weisz R. (2011). Emotions At Work: The Role Of Emotional Intelligence And Emotıonal Labor In Predıctıng Work-Famıly Conflıct, Psychological Distress, And Life Satısfactıon. International Journal of Arts and Sciences, 4(3), 29-44.

Karpuzoğlu, E. (2001). Büyüyen ve Gelişen Aile Şirketlerinde Kurumsallaşma (1 ed.). İstanbul: Hayat Yayınevi.

Karpuzoğlu, E. (2004). Aile Şirketlerinin Sürekliliğinde Kurumsallaşma. Paper presented at the T.C. İstanbul Kültür Üniversitesi 1. Aile İşletmeleri Kongresi, İstanbul.

Oral, L., and Köse, S. (2011). Hekimlerin Duygusal Emek Kullanımı İle İş Doyumu Ve Tükenmişlik Düzeyleri Arasındaki İlişkiler Üzerine Bir Araştırma. [A Research On Phsıcıans’ Use Of Emotional Labor And The Relationshıp Between Their Job Satısfactıon And Burnout Levels]. Süleyman Demirel Üniversitesi İktisadi ve İdari Bilimler Fakültesi Dergisi, 16(2), 463-492.

Peltekoğlu, F. B. (1997). Kurumsal İletişim Sürecinde İmajın Yeri. Istanbul Üniversitesi Iletisim Fakültesi Dergisi, 125-146.

Sait Gürbüz, and Faruk Şahin. (2014). Sosyal Bilimlerde Araştırma Yöntemleri Felsefe Yönetim - Analiz. Ankara: Seçkin Yayınc1lık.

Shabana, K. M., Buchholtz, A. K., and Carroll, A. B. (2017). The institutionalization of corporate social responsibility reporting. Business and Society, 56(8), 1107-1135.

Tefek, A., Çetinkaya, A. S., and Karayel, S. (2018). Institutionalization in SMEs. Paper presented at the 11 th International Conference on New Challenges in Management and Business Hilton Istanbul Kozyatagi, Istanbul, Turkey.

Ulukan, C. (2005). Girisimcilerin ve Profesyonel Yöneticilerin Kurumsallasma Perspektifi. [Perspectives of Institutionalization of Entrepreneurs and Professional Managers]. Anadolu Üniversitesi Sosyal Bilimler Dergisi, 5(2), 29-42.

Ural, E. G. (2002). İtibar Yönetimi Değer Yaratan Bir Halkla İlişkiler Çalışması Olarak İtibar Yönetimi. İstanbul Ticaret Üniversitesi Dergisi, 1(2), 83-93.

Yong, A. G., and Pearce, S. (2013). A Beginner's Guide to Factor Analysis: Focusing on Exploratory Factor Analysis. Tutorials in Quantitative Methods for Psychology, 9(2), 79-94. 